It is evident from an examination of the total yields that liming was highly beneficial in connection with all of the phosphates, excepting the floats, and when the relative production of large and small tubers is considered, great benefit is shown even in that case.

These results further support the earlier observations at the Station to the effect that liming may increase the total yield of potatoes but that even if this is not the case the yield of tubers of large size is usually greatly increased on a soil like that under experiment.

The wide differences in yield shown upon the several plats, when the results are compared with those where no phosphate had been used, show that the after-effect of floats, bone meal, basic slag meal and of all of the superphosphates, is great, and long continued, both on the limed and unlimed land.

As concerns the total yields, it will be seen that where no phosphate was used the crop was nearly three times as great on the limed as on the unlimed plat thus showing a percentage gain far in excess of that in any other case. Taking account of the large tubers it will be observed that the same holds true. Therefore, both the yields of large tubers and the total yields give evidence that liming had probably placed at the disposal of the crop more phosphoric acid than would otherwise have been available.

On the unlimed land the inefficiency of the raw and roasted iron and aluminum phosphates is most striking, whether judged by the total yields or by the yields of large tubers. On the limed land the results with the raw iron and aluminum phosphate were poorer than where no phosphate had been used, but the roasted iron and aluminum phosphate gave results superior to those secured with acid phosphate, basic slag meal, or floats. This furnishes therefore a most striking example of the effect of applications of lime upon the continued efficiency of roasted iron and aluminum phosphate even when the last applications of each were made several years previous.

Notwithstanding that the floats had been drawn upon less heavily in previous years, by virtue of smaller crops, than most of the other phosphates, they proved far less efficient on the limed land than any of the others excepting the raw iron and aluminum phosphate which showed a negative value. On the unlimed land they gave, however, a better result than the dissolved bone-black, double superphosphate or roasted iron and aluminum phosphate, and they proved essentially as efficient as the acid phosphate. Doubtless this may be accounted for in some measure by the tendency of tri-calcic phosphate to correct the acid condition of the soil, in which it was aided by a small amount of carbonate of lime, probably present in the floats. This view is supported by the excellent results with basic slag meal, which contains a considerable excess of lime, and hence can over- come soil acidity in a greater degree than any of the other phosphates that were employed.

These results with floats, under the conditions existing where no lime was applied, cannot be cited to show that floats are equal in value to the other phosphates, for the reasons that the conditions of the soil were not such as to produce a normal crop under any conditions, as shown by the wonderful improvement in the yields after liming. Furthermore, when more nearly optimum conditions were created, as a result of liming, the floats then became decidedly inefficient in comparison with the other phosphates. This question of optimum conditions, in other respects, is a point in connection with comparative tests of phosphates and discussions of them which deserves great consideration if one hopes to arrive at reliable conclusions.

\section{A CONTRIBUTION TO OUR KNOWLEDGE OF THE NITROGEN PROBLEM UNDER DRY FARMING.}

By F. J. ALWAy AND R. S. TRUMBULl.

The development of so-called "dry farming" or "dry-land farming" on the semi-arid portions of the prairies of North America has introduced problems in soil fertility distinct from those of humid or of irrigated soils. The characteristic feature of dryland farming, in so far as it relates to the soil, is the practice of bare fallowing to store water in the subsoil, a practice, well known to cause, in humid regions, a rapid decline in soil nitrogen, the portion removed in the form of crops being only a small part of the whole that is lost. While in the least arid portions of the semi-arid regions certain intertilled crops may be found capable of taking the place of the fallow to some extent, such a change in cultural methods is not likely to lessen in any considerable degree the rate of loss of nitrogen. The use of leguminous crops as green manures has been advised as a substitute for the fallow. ${ }^{1}$ The growth of the legumes, however, exhausts more or less of the moisture which fallowing would conserve, thus increasing the supply of nitrogen at the expense of that of water and so defeating the very object of the fallow.

Investigations in dry-land farming on the Great Plains have been undertaken only so recently by experiment stations in the United States that data are not yet available to indicate how serious the nitrogen problem is, how soon it will become acute, or how best to solve it. For twenty-two vears, however, an experimental farm has been maintained by the Canadian government at Indian Head, Saskatchewan, and during the whole of this time the practice of bare fallowing has been employed for the conservation of moisture, it having been introduced in to the Canadian Northwest by Mr. Angus Mackay, who has been

1 Chilcott, "Dry-land Farming in the Great Plains Area." Year-book, U. S. Dep't of Agr., 1907. 
superintendent of this farm since its establishment in I887. It has been pointed out that this farm is located in a region properly considered semi-arid and that moisture studies of the subsoil clearly show the function of the summer-fallow. ${ }^{1}$

It is to be expected that the soil nitrogen supply will become an immediate economic problem in some parts of the semi-arid region much sooner than in others. Considering the five widely separated points of Indian Head in Saskatchewan, North Platte in Western Nebraska, Amarillo in Northwestern Texas, Solano in Northeastern New Mexico, and Douglas in Southeastern Arizona, we have a range of 400 per cent. of nitrogen as shown by the accompanying table. The samples analyzed were taken by one of us from the heavier types of soil, and accordingly, from those richest in nitrogen and organic matter. All the samples were composites, taken to a depth of six inches from virgin prairies.

Table I.-Nitrogen and Organic Carbon in Semi-arid SoIls.

\begin{tabular}{|c|c|c|}
\hline & $\begin{array}{l}\text { Nitrogent } \\
\text { Per cent. }\end{array}$ & $\begin{array}{c}\text { Organic } \\
\text { carbon. } \\
\text { Per cent. }\end{array}$ \\
\hline Indian Head, Saskatchewan... & 0.384 & 4.20 \\
\hline North Platte, Western Nebraska. & 0.175 & 2.06 \\
\hline Amarillo, Northwestern Texas. & 0.136 & 1.37 \\
\hline Solano, Northeastern New Mexico... & 0.161 & 1.28 \\
\hline Douglas, Southeastern Arizona ............ & 0.087 & 0.58 \\
\hline
\end{tabular}

In order to be able to form some idea as to the losses of humus, of total organic matter and of total nitrogen induced by continuous cultivation under semi-arid conditions, one of us visited the Indian Head Experimental Farm in October, 1907, and secured over 70 samples of soil to a depth of six inches from various fields, plots, etc., as well as from the adjacent prairie. In the case of each sample the total nitrogen, the humus and the organic carbon were determined, but in many cases in the results reported below only the averages of series are given. The humus was determined by the Hilgard method and the organic carbon by combustion with copper oxide after the carbonates had been decomposed by treatment with phosphoric acid.

The data in regard to crop yields and the history of the fields have been secured partly from the annual reports of the Canadian Experimental Farms and partly from private information furnished by Mr. A. Mackay.

Shut ${ }^{2}$ had shortly before called attention to the fact that while the yield of wheat at Indian Head has not shown any marked diminution, there has been a loss of o.r I 8 per cent. of nitrogen to a depth of eight inches during twenty-three years of cultivation, while the amount contained in the various grain crops produced during this period he calculated to be less than onethird as much as had been lost from the soil. He did

1 Am. Chem. Jour., 31, 580 (1906); Jour. Ag̈r. Sci., 2, 333 (1908); Bull. 130, Bureat of Plant Industry, p. 17 (1908).

2 Address of the chairman of the Section of Agr. Chem. at the Toronto meeting of the American Chemical Society, June, 1907. Science, N. S., 26, 661 . p. 265 (1907). not determine the organic matter, but, on the basis of his studies of the soils of humid eastern Canada, concluded that the total nitrogen and the organic matter rise and fall together.

The farm was part of the prairie until I882 when it was all plowed and during the next five years kept in small grain. The whole was kept in clean summerfallow in 1887 , the year the government took possession, since which time the history of the difierent fields has not been the same.

One field which from I $889-1898$ had had the following succession of crops: aats, fallow, roots, barley, fallow, roots, fallow, wheat, oats and fallow, was in I 899 divided in twenty-two one-half acre plots which have since been continuously used for rotation experiments. The character of the rotation is indicated in Table II. Lacustral clay forms the surface of the greater portion of the field, varying in depth from a few inches to three feet. The remainder of the surface consists of boulder clay, or till, which also everywhere underlies the lacustral clay. The fallowing has consisted of one plowing early in June followed by three or four cultivations during the summer, this being sufficient to keep down all grass and weeds. Where one cereal crop has been followed by another, or by a legume or by rape, the stubble has been plowed in late summer or in autumn, and in the following spring harrowed and plowed again before seeding. The rape and leguminous plants have been turned under when

Table II,-Humus, Nitrogen and Organic Carbon in Surface Six INCHES OF SOIL OF THE ROtation Plots.

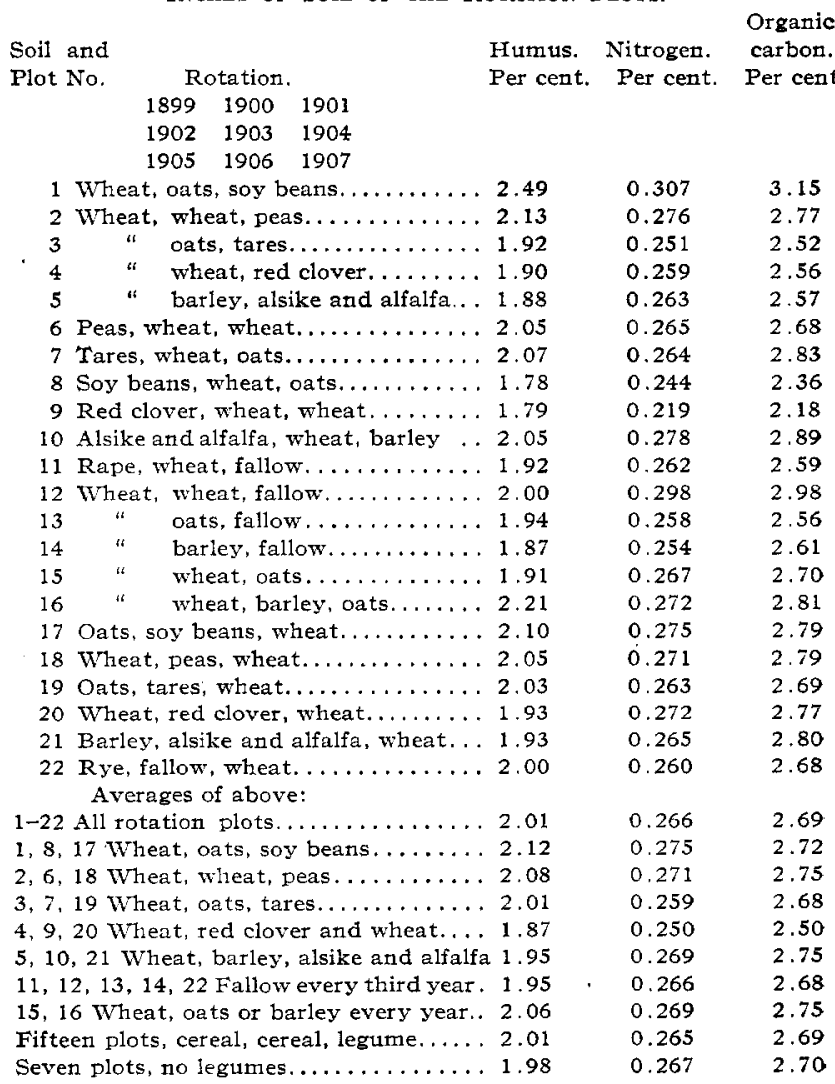


they have appeared to have reached their heaviest growth.

The most striking result of the analyses is the lack of any apparent connection between the composition of the samples and the treatment received by the different plots during the last nine years. No. I, the sample highest in humus, nitrogen and carbon, is from a plot on which three crops of legumes have been plowed under, while the samples showing the least of the same constituents, viz., 8 and 9 , are likewise from plots on which three crops of legumes had been plowed under. A comparison of the averages shows no distinct difference between the fifteen plots on which legumes had been used as green manure and the other seven.

That an explanation of the differences between the different plots is possible is evident from the data in Table III. Suspecting that distinct differences might be found between different individual samples from the same plot, according as to whether they were from the till or from the lacustral clay, ten individual samples from rotation plot $\mathrm{I}_{4}$ were kept separate and analyzed. Till forms the surface of the west third of this plot and of an isolated area near the center, while the east end has a surface of typical lacustral clay. Near the edge of this area of lacustral clay and about twenty feet within it, five samples, 24 to 28 , were taken at intervals of ten feet in a north and south line, and, beginning twenty feet west of 26 , five samples, 29 to 33 , were taken at intervals of eight feet in an east and west line. While 29 and 30 are really typical of neither type, being intermediate between the two, 3 I to 33 are quite representative of the till, being from the isolated area above mentioned, and 24 to 28 are fair samples of the lacustral clay.

Ta ble III.-Humus, Nitrogen and Organic Carbon of Individual SaMples from the Same Plot.

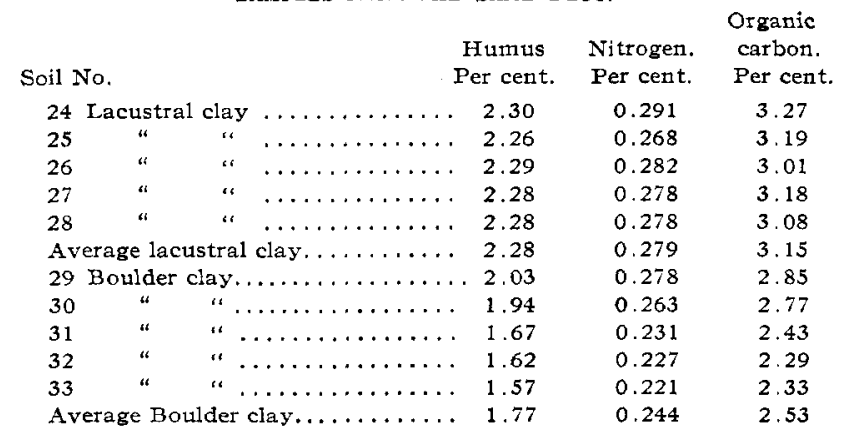

The samples of lacustral clay are richer in humus, total nitrogen and carbon than are those of till. From the differences found between the two types of soil on the same plot, it seems probable that the differences found between the different plots should be attributed chiefly to the varying amounts of the two types of surface soil.

Samples were secured from other fields and also from tree rows which had for the preceding is years been under continuous bare cultivation. These rows of trees were planted along the lanes in 1892 and since that time the soil for a distance of twelve feet on each side of the trees has every summer been plowed and cultivated sufficiently to prevent the growth of grass or weeds. A summary of the results are given in Table IV.

TABle IV.-Relation of Composition of Surface Six Inches of Soll to Cultivation.

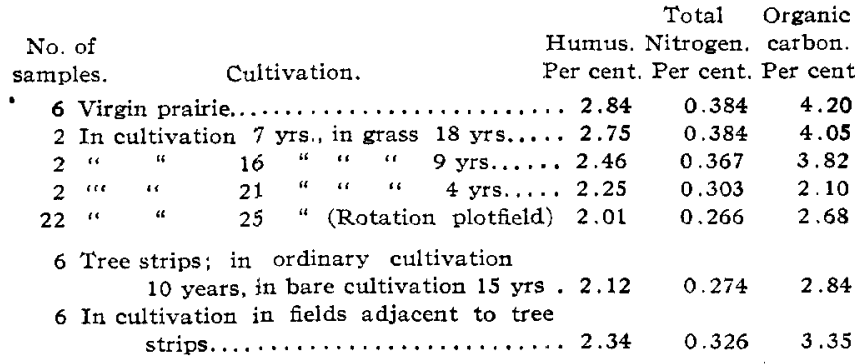

It is impossible from the data on hand to satisfactorily estimate the original composition of the virgin prairie where lacustral clay occurs. ${ }^{1}$ The numbers given in the first line of the table are the averages of samples from the boulder clay and from the lacustral clay summits. The numbers are certainly too low because samples from some fields long under cultivation give slightly higher percentages than these. On soil where grass (in this case mixed with clover) has grown for 18 years, following 7 years of cultivation, no distinct loss is to be observed. The longer the fields have been in grass the less has been the decline. Where no grass at all has been grown the loss is greatest. Continuous bare cultivation in the tree rows has caused greater losses than where bare cultivation (fallow) and cropping have alternated. The extreme loss is probably about one-third of the original amount of all three constituents.

The data showing the effect upon the yield of wheat produced by replacing the summer-fallow by a leguminous crop plowed under as a green manure have been obtained chiefly from the field of rotation plots described above (Table II). A summary of the results is given in Table V. Judged by its crop-producing power, this field was very uniform in 1899 , the yield of the 12 plots of wheat ranging only from 35 bushel $20 \mathrm{Hb}$. to 36 bushel $16 \mathrm{Hb}$. per acre. The data for wheat after legumes in 1899 are from a series of halfacre plots in another field. On account of the little data on the yields after fallow in the rotation field there are given in the table the averages of all field lots of the standard varieties grown on summerfallowed land. There being no field or half-acre plots of wheat after fallow in I900 it has been necessary to employ the yield of a smaller plot. In 1902 the wheat after fallow on the three rotation plots was injured so seriously by rust that the yield was lower (20.3 bushel per acre) and the quality poorer than on any other plot or field on the farm. Accordingly this yield should not be used in such a comparison. 
Table V.-Yield of Wheat per Acre at indian Head after fallow, AFter Legumes Plowed UNDER, AND After WheAt.

\begin{tabular}{|c|c|c|c|c|c|c|c|c|}
\hline \multirow[b]{3}{*}{ Year. } & \multicolumn{4}{|c|}{ After fallow. } & \multirow{2}{*}{\multicolumn{2}{|c|}{$\begin{array}{c}\text { After } \\
\text { leguminous } \\
\text { green } \\
\text { manutes. }\end{array}$}} & \multirow{2}{*}{\multicolumn{2}{|c|}{$\begin{array}{l}\text { After } \\
\text { wheat, oats } \\
\text { and barley. }\end{array}$}} \\
\hline & \multicolumn{2}{|c|}{ Field lots. } & \multicolumn{2}{|c|}{ Check plots. } & & & & \\
\hline & Acres.. & $\begin{array}{c}\text { Yield. } \\
\text { bu. }\end{array}$ & $\begin{array}{l}\text { No. of } \\
\frac{1}{2} \text { acre } \\
\text { plots. }\end{array}$ & $\begin{array}{l}\text { Yield, } \\
\text { bu. }\end{array}$ & $\begin{array}{l}\text { No of } \\
\frac{1}{2} \text { acre } \\
\text { plots. }\end{array}$ & $\begin{array}{l}\text { Yield, } \\
\text { bu. }\end{array}$ & $\begin{array}{l}\text { No. of } \\
\frac{1}{2} \text { acre } \\
\text { plots. }\end{array}$ & $\begin{array}{c}\text { Yield, } \\
\text { bu. }\end{array}$ \\
\hline 1899 & 16 & 32.7 & 13 & 35.9 & 6 & 34.5 & 1 & 28.9 \\
\hline 1900 & 0 & $\ldots$ & $1^{2}$ & 27.0 & 5 & 14.9 & 4 & 5.4 \\
\hline 190 & 17 & 49.2 & 1 & 44.7 & 5 & 43.1 & 2 & 38.4 \\
\hline 190 & 40 & 33.4 & 3 & $\ldots{ }^{3}$ & 5 & 24.9 & 4 & 25.5 \\
\hline 1903 & 26 & 35.8 & 0 & $\ldots$ & 5 & 23.8 & 4 & 15.9 \\
\hline 1904 & 44 & 39.3 & 1 & 36.0 & 5 & 34.5 & 2 & 30.2 \\
\hline 1905 & 44 & 40.0 & 3 & 35.3 & 5 & 30.0 & 4 & 23.1 \\
\hline 1906 & 45 & 30.5 & 0 & $\ldots$ & 5 & 20.7 & 4 & 16.5 \\
\hline Wer & & 34.6 & . & $\cdots$ & . & 28.3 & . & 22.9 \\
\hline
\end{tabular}

In two years, I 899 and I9OI, when the previous harvest had been followed by exceptionally wet weather, the yield after legumes was about the same as that after fallow, the autumn rainfall probably having been sufficient to fully charge with moisture the subsoil of all the fields. In the other years the legumes, by exhausting the water of the subsoil, lessened the yield of the succeeding crop. Wheat has given a lower yield when sown on wheat stubble than after legumes, chiefly because the soil has been left drier in the autumn, although partially, probably because the supply of available nitrogen has been less. Even in the case of the two wet years mentioned, the difference in yield is considerable.

The data in Table VI seems sufficient evidence that, notwithstanding a decline of 30 per cent. or more in soil nitrogen, this element has not yet become a limiting factor in the yield of wheat on fallowed land at Indian Head. The table gives the yield of Red Fife wheat both without any fertilizers and with Ioo tbs. and $200 \mathrm{Hs}$., respectively, of sodium nitrate. The plots were on fallowed land in every case, soil not previously fertilized being taken each year. In I903 all the plots in the fertilizer experiments were so badly injured by rust that the crop was not weighed. The average yields of the three plots for the remaining six years were practically the same. No trials are reported of the use of nitrates on wheat sown on stubble.

- Table VI.-Yields of Wheat at INdian Head with and without NiTROGEN FERTILIZERS.

\begin{tabular}{|c|c|c|c|c|c|c|}
\hline \multirow[b]{2}{*}{ Year, } & \multicolumn{2}{|c|}{ No fertilizer. } & \multicolumn{2}{|c|}{100 tbs. $\mathrm{NaNO}_{3}$} & \multicolumn{2}{|c|}{200 tbs. $\mathrm{NaNO}_{3}$} \\
\hline & $\begin{array}{l}\text { Straw, } \\
\text { cwt. }\end{array}$ & $\begin{array}{c}\text { Grain, } \\
\text { bu. }\end{array}$ & $\begin{array}{l}\text { Straw, } \\
\text { cwt. }\end{array}$ & $\begin{array}{c}\text { Grain, } \\
\text { bu. }\end{array}$ & $\begin{array}{c}\text { Straw, } \\
\text { cwt. }\end{array}$ & $\begin{array}{c}\text { Grain. } \\
\text { bu. }\end{array}$ \\
\hline 1900 & 17.4 & 27.7 & 17.6 & 27.3 & 17.6 & 27.3 \\
\hline 1901 & 66.0 & 62.7 & 59.2 & 61.3 & 54.8 & 58.7 \\
\hline 1902 & 37.6 & 29.2 & 31.6 & 28.0 & 38.8 & 30.7 \\
\hline 1904 & 28.6 & 26.3 & 30.4 & 28.7 & 26.4 & 23.0 \\
\hline 1905 & 72.4 & 42.7 & 62.8 & 42.0 & 54,0 & 43.3 \\
\hline 1906 & 48.0 & 35.3 & 62.4 & 38.0 & 52.4 & 38.0 \\
\hline Average, & 45.0 & 37.3 & 44.0 & 37.5 & 40.7 & 36.9 \\
\hline
\end{tabular}

There are two distinct causes of a lowering of the content of organic matter, humus, and nitrogen of cultivated soils at Indian Head, viz., the oxidation of the organic matter and the erosion of the surface soil

\footnotetext{
1 Two 3-acre fields.

2 A fortieth-acre plot.

3 Badly injured by rust.
}

by the wind. The deeper the layer of soil is, the lower is the content of humus and nitrogen; accordingly, erosion by the wind will have an effect upon the humus and nitrogen content similar to that of cultivation and may seriously affect the value of any such soil study as this.

The seriousness of the nitrogen problem for the semi-arid region as a whole is evident when it is considered that the loss in 25 years at Indian Head has been almost equal to the total percentage in the virgin soils of northwestern Texas and to much more than that in the virgin soils of Southern Arizona. Further, the use of a theoretically good rotation with leguminous green manures over a period of nine years has failed to have any appreciable effect in checking the rapid loss of soil nitrogen, while it has greatly lessened the yield of grain.

\section{SUMMARY.}

In a comparison of 22 rotation plots no distinct relation has been found between the composition of the soil and the nature of the rotation. In a long cultivated field the till was found poorer in humus, nitrogen and organic carbon than the lacustral clay. The amounts of the above three constituents found in any of the plots depend more upon the relative proportions of the two types of soil occurring on the plot than upon the previous treatment.

The longer the fields have been kept in grasses mown for hay, the less has been the change in composition of the soil. Continuous bare cultivation along tree rows has caused greater losses than the alternation of fallow and erop in the adjacent fields. The extreme loss of nitrogen, humus and organic carbon in 25 years is about one-third of the amounts originally present in the prairie. This loss of nitrogen is not sufficient, however, to cause nitrogen to have become a limiting factor in the yield of wheat on fallowed land at Indian Head.

Attempts to substitute for the bare fallow various leguminous crops, which have been plowed under, have decreased the yields of wheat. The lowered yields are evidently due to the drying out of the soil by the leguminous crop. In the exceptional years when the rainfall of autumn has been very heavy the yields after legumes have been as high as after fallow.

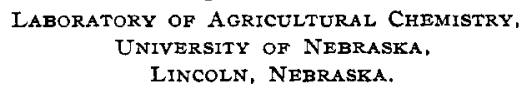

\section{NITROGEN AND CARBON IN THE VIRGIN AND FALLOWED SOILS OF EASTERN OREGON.}

\author{
By C. E. BRADIEY. \\ Received January, 19, 1910.
}

The great wheat belt of Eastern Oregon is characterized by a silt loam soil. The deposits are of volcanic origin and are remarkably uniform in structure even to considerable depths. The rainfall in this 